\title{
Investigating Impact of US, Europe, Frontier and BRIC Stock Markets on Indian Financial Stress Index
}

\author{
Amanjot Singh ${ }^{1}$ \\ University School of Applied Management, Punjabi University, Patiala, India 147002 \\ Email:amanjot_42@yahoo.com \\ Manjit Singh \\ University School of Applied Management, Punjabi University, Patiala, India 147002 \\ Email:smanjitt@gmail.com
}

Received: 25 December 2015 / Revised: 3 April 2016 / Accepted: 20 April 2016 / Published online: 16 June 2016

\begin{abstract}
The emerging markets are slowly opening up their respective financial markets to foreign investments, thereby making the latter markets more sensitive to cross-market information transmissions. There are different transmission mechanisms ranging from trade related to financial linkages. However, statistically, both price discovery and conditional volatility act as transmission mechanisms, whereby information in one stock market has an impact on another. In this regard, the present study attempts to empirically analyse the impact of global information transmissions, i.e., stock market returns and conditional volatility on overall Indian financial stress and its various sub-components by employing different econometric models comprising Johanson Cointegration, Vector Autoregression and its various counterparts, Component GARCH $(1,1)$ model and multivariate OLS regression models ranging from October 2003 to October 2014. The study firstly constructed Indian financial stress index owing to non-existence of a standardised index. The results reported that the one month lagged returns in the BRIC stock markets have an impact on the financial stress index of India. The stress in the Indian financial system responds statistically significantly to the Brazilian and Chinese market returns, with a greater degree of integration after two months. A statistically significant impact of the shortrun volatility has also been observed running from the European markets to the Indian financial system contemporaneously. Furthermore, unexpected volatility in the BRIC markets also has an impact on the Indian financial stress contemporaneously as well as dynamically. The present study provides an insight to the international investors regarding the response of Indian financial system and its sub-components toward global information transmissions.
\end{abstract}

JEL classification: F36; G10; G15

Keywords: BRIC, financial stress, frontier markets, transmission

Corresponding author; Postal address \#303-C, Rajguru Nagar, Ludhiana, Punjab, India 141012. 


\section{INTRODUCTION}

The markets all over the world and especially the emerging ones are slowly opening up their equity markets to the foreign direct as well as portfolio investors. The increased globalisation and the development of the trading platforms have made the countries prone to an international crisis and the country specific news and events gets transferred from one country to another impacting the embedded trading nations (Angkinand et al., 2010). A simple example to comprehend the integration of the markets can be that of the United States (US). The developments in the US and the likely decision of the Monetary Authorities to end the Quantitative Easing cycle started as a result of the 2008 crisis make the Indian equity markets or in a broader sense the emerging markets witness a downward rally as the quest to transfer the 'Hot Money' from the emerging nations to the safer ones increases. Frank and Hesse (2009) reported spillover of the crisis from the developed markets to the emerging markets highlighting the safety concerns of the international investors in their act of transferring money from the emerging nations.

Price discovery can be denoted as the speed at which an asset's price reacts to new information (Booth et al., 1999). Apart from price discovery, conditional volatility also acts as another information transmission mechanism, wherein information in one stock market has an impact on another country's stock market (Gagnon \& Karolyi, 2006; Rittler, 2012). So, due to increased integration and international portfolio allocations, the stock market returns and volatility in one market get transferred to the stock markets of other countries. Numerous studies have captured the contagion impact of the country specific events on the other integrated economies (see Worthington \& Higgs, 2004; Mukherjee \& Mishra, 2010 and Kharchenko \& Tzvetkov, 2013; etc.). Now a question arises whether these spillovers have an impact on the financial stress of the recipient country owing to international flow of funds. The present study attempts to answer the question posited by employing Vector Autoregression model (VAR model) and Component Generalised Autoregressive Conditional Heteroskedastic model [CGARCH $(1,1)$ model]. The impact of the first moment as well as the second moment of the stock market has been covered in the study; the impact of the global stock market returns and volatility on the Indian financial stress respectively. We have considered the stock markets of the US, Europe, frontier markets and the BRIC (Brazil, Russia, India and China) markets, thereby taking into account the case of two developed economies (the US and Europe) and two developing economies (BRIC countries and frontier countries). The frontier markets like Kuwait, Tunisia, Pakistan, etc., which are economically lesser developed even compared to the emerging markets, are also included in the study as an endogenous variable making the study first of its kind. A priori one would expect a higher degree impact of the US and BRIC equity markets on the Indian financial system and its sub-components because of the increasing integration in the sense of real as well as financial linkages among the countries concerned and the US being the dominant economy worldwide. Moreover, the steps taken in the direction of incorporation of the BRICS bank and increasing flow of foreign funds act as a base for considering the higher impact of the BRIC markets on the Indian financial system. Besides this, we expect that falling returns in the respective equity markets will have an increasing impact on the financial stress in the Indian economy.

A financial stress in a general sense implies commotion in the asset prices and the failure of financial institutions (Manamperi, 2015). There is no specific definition available for the financial stress, but in a layman terms, it is a stress or uncertainty in the financial sector of an economy which further has an impact on the macroeconomic conditions. A stress in the financial system which not only comprises equity market but also debt market, money market, commodity market as well as currency market has an impact on the fundamental health of an economy. Any disruption in a financial system makes the economies feel the heat of the lower output, higher bank rates, increased unemployment, lower GDP growth, higher inflation, etc. Hakkio and Keeton (2009) explained the various features of the financial stress, ranging from uncertainty about the fundamental value of 
assets, uncertainty about the behaviour of investors, increased asymmetry of information, flight to quality investment avenues to flight to liquidity. The review highlights the fact that the global macroeconomic conditions or a country specific crisis does have an impact on the financial stress of a country like what happened during the subprime episode in the US, as studied by Bianconi et al. (2013). During the period of a financial stress, this increased integration across different markets proves to be a bane as the financial stress gets spillovered from one market to another through the channels of trade as well as the financial markets. Therefore, a study to account for the impact of the global market returns and volatility on the Indian financial stress has been undertaken.

Over a period of time, many researchers have tried to capture the financial stress in an economy. Particularly the work relates to the developed markets as compared to the emerging markets. A reason that could be attributed to this can be the development level of financial markets in the emerging nations and the availability of the data therein. Kliesen et al. (2012) explored various financial stress indices across different countries and found out the co-movement among them. The authors gave a very comprehensive review of the stress indices, like STLFSI (St. Louis Fed Financial Stress Index), KCFSI (Kansas City Financial Stress Index) and CFSI (Cleveland Financial Stress Index) are some of the indices to account for the US financial stress. Apart from the US, the indices have been designed keeping in view the financial aspects of other countries as well, like Canada (Illing \& Liu, 2006), Sweden (Sandhal et al., 2011), Colombia (Morales \& Estrada, 2010), Hong Kong (Yiu, Ho, \& Jin, 2010), etc. But there are some studies which have also concentrated on the emerging markets and have developed the financial stress indices. Balakrishnan et al. (2011) and Park and Mercado (2013) investigated the determinants of the financial stress in the emerging markets as well as the transmission of the global financial crisis. The studies relating to the financial stress are not only limited to the designing of the indices yet an effort has been made by every author to either explore the impact of a global or inter-regional or intra-regional shock on the financial stress index. Furthermore, the impact of the financial stress on the economic activities has also been studied by the scholars (Davig \& Hakkio, 2010). Sum (2013) examined the impulse response functions of the Federal Reserve Bank of St. Louis financial stress index and excess returns on the CRSP (Centre for Research in Security Prices) value-weighted index. The author observed that the financial stress Granger-causes market risk premiums to drop significantly. Moreover, there is no reverse causation. The studies, like Goldstein and Xie (2009), Roye (2014) and Wallace (2013), have captured the impact of the financial stress on economic activities across different countries with the findings that the financial stress does have an impact on different economic activities of an economy like GDP, inflation numbers, etc. There are some studies which have gone one step ahead and tried to account for the impact of the financial stress on the stock markets as well (see for detail Christopoulos et al., 2011 and Rachdi, 2013). Almost all of the studies have analysed the impact of the financial stress on some type of economic activity, but till now not much work has been done to see what factors have an impact on the financial stress, particularly the impact of global stock markets on the domestic financial stress. The present study attempts to fill this research gap.

A study relating to the impact of the global stock markets on the domestic overall financial stress is an imperative task to be performed by the policy makers as well as the investors. The results reported by the models employed signify the existence of an impact from the BRIC and the European nations to the Indian financial system, making a case for the financial market investors and the policy makers to discount this type of information well in advance. Moreover, the results provide an insight to the international investors regarding the response of Indian financial system and its sub-components toward global information transmissions.

The paper has been divided into five sections. Section 2 explains the construction of the financial stress index in the Indian economy context. Section 3 highlights the methodology used to account for the impact of the markets on the financial stress. Sections 4 and 5 introduce the readers to the empirical findings and the concluding remarks thereof. 


\section{CONSTRUCTION OF FINANCIAL STRESS INDEX}

A financial system comprises various segments like the equity markets, debt markets, foreign exchange markets and money markets. In order to construct the financial stress index, we have taken all of these four segments into account. The index has been constructed following the work of Balakrishnan et al. (2011), Yiu, Ho, and Jin (2010) and Park and Mercado (2013). The latter studies have considered these four segments to account for the possible macroeconomic channels having an impact on the financial stress of an economy. We have collected monthly data for a period of 11 years with effect from October 2003 up till October 2014 from the Bloomberg and Yahoo Finance Database as per its availability. Our reason for taking monthly values instead of daily values is that monthly values of the indicators would reduce the sensitivity and enhance the reliability of the data in comparison to the daily data.

To capture the impact of global stock markets on the Indian financial stress index, we have taken Morgan Stanley Capital International (MSCI) indices: MSCI US, MSCI Europe, MSCI frontier markets and MSCI BRIC markets. Likewise, we have taken monthly closing values from the website of MSCI ranging from October 2003 to October 2014. The period assumed for the study has been decided keeping in view the availability of the data. All of the MSCI indices are designed by taking large cap and mid cap scripts from the respective nations. For instance, MSCI BRIC index comprises good quality stocks from Brazilian, Russian, Indian and Chinese markets. The monthly continuously compounded returns are calculated for the MSCI indices.

\subsection{FSI Variables}

To capture the stress in the equity market, we have taken the NIFTY index returns and volatility. The NIFTY index monthly continuously compounded returns have been calculated as:

$$
R_{t}=\operatorname{Ln}\left(P_{t} / P_{t-1}\right) * 100
$$

where $R_{t}$ is the monthly return, $P_{t}$ is the current month close price and $P_{t-1}$ is the previous month close price. We have taken the NIFTY index returns as it is without really considering the impact of only negative returns on the financial stress index because it has been observed that increased conditional volatility is also concerned with the negative market returns (Christie, 1982). So, the study has considered overall stock market returns. To model the volatility in the NIFTY index, we have employed GARCH $(1,1)$ model. The standardised values ${ }^{2}$ are taken for the equity market return and volatility series. To calculate the standardised values, the mean value is firstly deducted from the series and then divided by the series' standard deviation.

The stress in the banking sector has been captured by the spread between MIBOR 3 monthly rate and Treasury Bill 3 monthly yield. The spread exhibits stress in the liquidity and the interbank lending risks. An increased spread indicates increased interbank lending rates, thereby depicting the liquidity funding risk in an economy. Again, we have taken the standardised values. The banking sector BETA is generally taken as a parameter for measuring the banking stress; however, due to non-availability of the data during the period concerned, we have taken only MIBOR 3-month rate - Treasury bill 3-month yield spread as the stress measurer.

$$
\begin{gathered}
\mathrm{FSI}=\text { Equity Market Return }+ \text { Equity Market Volatility }+ \text { Debt Market }(\text { Spread }) \\
+ \text { Baking Sector }(\text { Spread })+\text { Exchange Rate Volatility }
\end{gathered}
$$

\footnotetext{
$Y_{t}=\frac{\left(X_{t}-\text { Mean Value }\right)}{\text { Standard Deviation }}$
} 
For an emerging market like India, the major worry with regard to the foreign exchange market is the volatility in the exchange rate due to very high twin deficits (fiscal deficit and current account deficit) and interest rates. The GARCH $(1,1)$ model has been used to account for the volatility in the Dollar/Rupee exchange rate. Again, we have taken the standardised values. To capture the stress in the sovereign debt, we have taken standardised spread between the India Government securities 10-year yield and the US Government securities 10-year yield. An increased value of the spread means an increased sovereign debt servicing risk. These five components of the financial markets represent overall financial stress in an economy. A reason for taking only these four segments of the financial system into account is that these segments are the core segments to measure a financial stress in an economy. Other indicators which can also be taken as a part of measuring the overall financial condition can be the GDP growth rate, unemployment levels, inflation index, etc. However, in the present study we are relying only on the core financial stress indicators for measuring overall financial stress instead of financial condition. Another important part of the construction of the index is the weighting scheme of different components.

\subsection{Weighting Scheme of the Index}

The literature describes various weighting schemes used by the researchers over a period of time. For instance, unweighted index, equal weighted index, market weighted index, principal component analysis, etc., are some of the methods that have been used to construct the financial stress index. In the present study, we have employed unweighted index, equal weighted index and principal component analysis so as to capture the financial stress in the Indian economy. Under the unweighted index approach, an aggregative value of respective standardised variables is taken up as an index value at time $t$ and so on. The aggregate values are further re-based in the range of 0 to 100, by employing the following formula, as inspired from Lall et al. (2008):

$$
\text { New Scale Value }=\frac{\text { Old Scale Value }- \text { Lowest Value }}{\text { Highest Value }- \text { Lowest Value }} * 100
$$

Another method of creating an index is principal component analysis, which identifies the best possible combination of the variables that explains the total variance in the five variables. Firstly, the standardised values are factored into the model and then the normalised component loadings/ coefficients (component loadings divided by the square root of respective communalities) are calculated. The coefficients identify the impact of one standard deviation change in the variable on the financial stress index. In the present study, the second component explained around 66 percent of the total variation in the five variables. So, the normalised component loadings of the second component pave the way for the computation of financial stress index values by taking an aggregative value of respective variables over a period of time. In the last step, the index values are re-based in the range of 0 to 100 .

Lastly, to calculate equal weighted financial stress index, we have computed average values of the sub-components of the financial stress. Before taking an average, respective standardised series of each sub-component are re-based within the range of 0 to 100. So, by taking the average values of different components of the financial stress, we allocated equal weights to each component in the financial stress index. 


\section{RESEARCH METHODOLOGY}

In order to model the impact of the returns on the financial stress, we have employed VAR model (Vector Autoregression model) and to model the impact of the global stock market volatility on the Indian financial stress index, CGARCH $(1,1)$ model has been used. Before applying the VAR model, an effort has also been made to check a long-run stochastic trend among the variables concerned by using Johansen Cointegration Approach.

\subsection{Vector Autoregression Model}

The efficiency of the VAR model in capturing dynamic relationships among the underlying variables is well documented. Under the VAR model, a dependent variable is a function of its own lagged values as well as the lagged values of some other variable. The model has been popularised by Sims (1980). Due to its dynamic nature, the VAR model is observed to be an optimal candidate accounting for first moment linkages among the markets. Say there are two variables $Y_{1}$ and $Y_{2}$, the VAR model equation shall be defined as follows:

$$
\begin{aligned}
& Y_{1, t}=c_{1}+A_{1,1} Y_{1, t-1}+A_{1,2} Y_{2, t-1}+e_{1, t} \\
& Y_{2, t}=c_{2}+A_{2,1} Y_{1, t-1}+A_{2,2} Y_{2, t-1}+e_{2, t}
\end{aligned}
$$

where $c_{1}$ and $c_{2}$ is a $k \times 1$ vector of constants, $A_{i}$ is a $k \times k$ matrix (for every $i=0, \ldots, p$ ) and $\mathrm{e}_{\mathrm{t}}$ is a $k \times 1$ vector of error terms known as impulses or shocks. The lagged values of the dependent as well as the independent variables help in analysing the dynamic impact of global stock market returns on the Indian financial stress index. To analyse the results of the VAR model, we have further employed Granger causality test, impulse response functions and variance decomposition analysis.

\subsection{Component GARCH $(1,1)$ Model}

To analyse the impact of the second moment, i.e. market volatility, on the financial stress in India, we have employed CGARCH $(1,1)$ model. The model demarcates conditional variance into two components: Transitory/Short-run component and the Permanent/Long-run component. The CGARCH model was introduced by Ding et al. (1993) as an advancement to the plain vanilla GARCH $(1,1)$ model introduced by Bollerslev (1986). Volatility is not directly observable in the market; however, it can be gathered from the past behaviour of the respective market prices. Subsequently, the GARCH based models are found to be effective in capturing the conditional variances or time-varying volatility. Under the plain vanilla GARCH model, a dependent variable is a function of its own past squared error terms and the past volatility. For the sake of simplicity, the GARCH models exhibit the impact of recent news/shock as well as the past volatility on the current conditional variance. The CGARCH model is an extension of the plain vanilla GARCH model wherein a conditional variance comprises two components: permanent and transitory. The conditional mean equation [eq (6)] and the variance equation under the CGARCH model framework are defined as follows:

$$
R_{t}=c+\varepsilon_{t}
$$

where $R_{t}$ is monthly continuously compounding return of the respective nations. The monthly returns are a function of only the constant term and $\varepsilon_{t}$ is the residual part. It may be noted that overall GARCH diagnostic tests support the inclusion of only the constant term in the mean 
equation with respect to all of the markets, except for the frontier equity markets. So, one and two months' lagged values are included in the mean equation of the latter markets, evidenced from significant autocorrelation coefficients. The residuals are further checked for the existence of the ARCH effects because there should be a volatility clustering phenomenon in the residuals derived from the mean equation so as to employ a GARCH model.

\section{Variance Equation}

$$
\begin{gathered}
q_{t}=\gamma_{0}+\gamma_{1}\left(q_{t-1}-\gamma_{0}\right)+\gamma_{2}\left(e_{t-1}^{2}-h_{t-1}\right) \\
h_{t}=q_{t}+\gamma_{3}\left(e_{t-1}^{2}-q_{t-1}\right)+\gamma_{4}\left(h_{t-1}-q_{t-1}\right)+\varepsilon_{t}
\end{gathered}
$$

where $q_{t}$ is the long-run component, $\left(e_{t-1}^{2}-h_{t-1}\right)$ highlights the time-varying movement of permanent/long-run component and $\gamma_{1}$ represents persistency in the long-run component. $\left(h_{t-1}-q_{t-1}\right)$ is transitory/short-run component of the conditional variance. The model has been estimated by assuming a normal distribution of the error terms. We have used the short-run and long-run component of conditional volatility to account for the impact of the volatility on the Indian financial stress. The short-run component of the conditional volatility is computed by deducting long-run component from the total conditional variance. Equations (7) and (8) bring to light the computational aspect of long- and short-run component of the conditional volatility in the context of the respective countries and regions considered. After the computation of respective conditional volatilities, we have tried to analyse the impact of those on the Indian financial stress index by using multivariate Ordinary Least Squares (OLS) regression model.

Equation (9) explains the impact of monthly transitory component on the monthly financial stress. On a similar note, we have captured the impact of monthly long-run component. The equation highlights the 'Contemporaneous Impact', i.e. same month impact of the volatility on the Indian financial stress index.

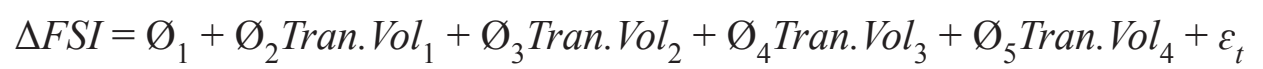

where $\varnothing_{1}$ is the constant term and $\varnothing_{2}, \varnothing_{3}, \varnothing_{4}$ and $\varnothing_{5}$ are the coefficients of the short-run components of the conditional variance relating to the BRIC, US, Europe and frontier nations respectively. However, one-month lagged impact of the conditional long-run as well as shortrun volatility has also been estimated to account for the 'Dynamic Impact'. Lastly, to capture the impact of the unexpected market volatility on the financial stress index, the standardised residuals $\left(e_{k, t}=\frac{\varepsilon_{k, t}}{\sqrt{\sigma_{k, t}}}\right)$ are derived from the respective variance equations (8).

$$
\Delta F S I=\infty_{1}+\infty_{2} \text { Uexp.Vol }+\infty_{3} \text { Uexp.Vol } 2+\infty_{4} U \exp . V_{3} l_{3}+\infty_{5} U \exp . V_{0} l_{4}+\varepsilon_{t}
$$

where $\infty_{1}$ is the constant term and $\infty_{2}, \infty_{3}, \infty_{4}$ and $\infty_{5}$ are the coefficients of the unexpected volatility relating to the BRIC, US, Europe and frontier nations respectively capturing the monthly contemporaneous impact. On a similar note, dynamic impact of one-month lagged unexpected volatility on the financial stress has been captured. For instance, equation (11) depicts one-month lagged impact of the unexpected component on the monthly financial stress:

$$
\begin{gathered}
\Delta F S I=\infty_{1}+\infty_{2} \operatorname{Uexp} . V_{1}(-1)+\infty_{3} \operatorname{Uexp}_{1} \operatorname{Vol}_{2}(-1)+\infty_{4} \operatorname{Uexp} . \operatorname{Vol}_{3}(-1)+ \\
+\infty_{5} \operatorname{Uexp}_{\operatorname{Vol}}(-1)+\varepsilon_{t}
\end{gathered}
$$


where $\infty_{1}$ is the constant term and $\infty_{2}, \infty_{3}, \infty_{4}$ and $\infty_{5}$ are the coefficients of the unexpected volatility capturing the dynamic impact relating to the BRIC, US, Europe and frontier nations respectively. The whole analysis has been done by using MS Excel and EVIEWS software.

\section{EMPIRICAL FINDINGS AND DISCUSSION}

Exhibit 1 reports graphical image of the Indian financial stress index by employing three different techniques. The index has captured stress in four different sub-sectors of the Indian financial system. The financial stress is very high in the last quarter of year 2008, thereby highlighting the presence of the US subprime crisis. It clearly shows spillover of the crisis from the US financial system to the Indian financial system.

As discussed earlier, we have used three different techniques to construct the financial stress index. The financial stress index measured through principal component analysis ${ }^{3}$ is quite volatile in comparison to the other techniques during the period 2003 to 2014. Interestingly, the timevarying movements of unweighted as well as equally weighted series are somewhat similar. At the same time, all of the financial stress indices have captured the existence of a high level of stress in the Indian financial system during the US financial crisis period, thereby confirming the adequacy of the Indian financial stress indices.

\section{Exhibit 1}

Indian Financial Stress Index

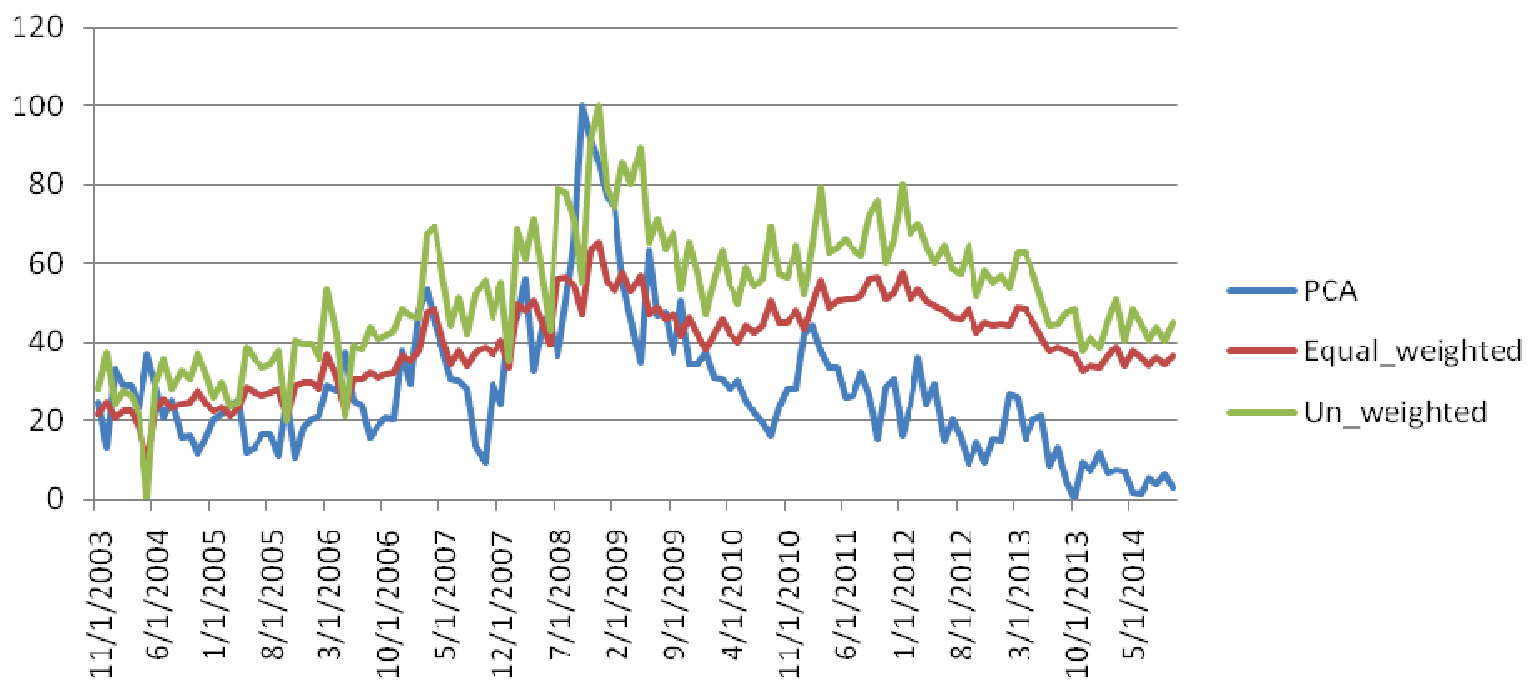

Source: Computed by the Authors

Considering the above facts, we have adopted a conservative approach to measuring the financial stress through equally weighted approach; relatively lesser as well as stable. So, the rest of the discussion and analysis has been done by taking equally weighted financial stress index. On a monthly average basis, the financial stress for years 2003 to 2014 is about 39.69 coupled with a very high standard deviation of 10.95 . The financial stress series is normally distributed at level because we failed to reject the null hypothesis of normal distribution of Jarque-Bera test (2.768, $\mathrm{p}>0.05)$. Exhibit 2 is the graphical presentation of respective MSCI indices for years 2003 to 2014. A downward rally can easily be seen during the period 2008-2009, thereby signifying

The respective standardised weights are $0.97,0.23,-0.29,0.94$ and -0.65 for bank spread, exchange rate volatility, debt spread, equity market volatility and equity market returns. A negative weight highlights an increasing impact of the respective variable during negative phases, for instance, negative equity market returns enhance financial stress. 
the presence of the US subprime crisis during that period worldwide. The crisis that started in the US spillovered to other countries owing to strongly integrated financial system and increasing international trade relations (Dooley \& Hutchison, 2009).

\section{Exhibit 2}

Graphical Presentation of MSCI Indices

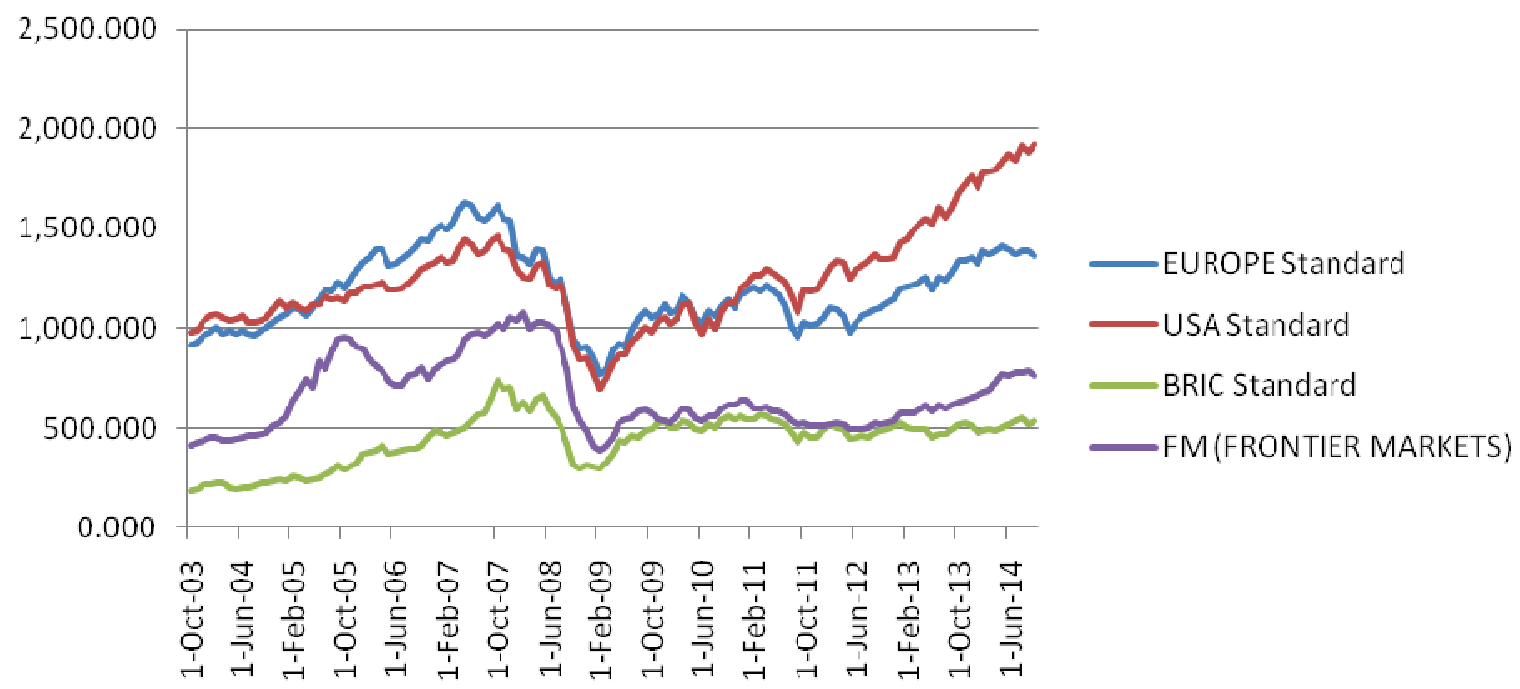

Source: Computed by the Authors

Exhibit 3 reports descriptive statistics of MSCI index returns with respect to all of the countries. The average monthly returns are observed to be highest for the BRIC countries during the sample period. The highest average returns for the BRIC countries signify positive behaviour of the investors toward opportunities available in the emerging markets. The emerging markets like the BRIC nations with increasing middle class population, technological up-gradation and infrastructure development provide immense opportunities to the domestic as well as international investors to reap out the investment benefits. The average returns in the frontier markets are also higher coupled with a higher level of standard deviation compared to Europe. The average values signify the fact that the emerging and frontier markets act as an investment opportunity for the international investors and more to those who are ready to digest an increased risk level. Notwithstanding, the BRIC countries witness higher average monthly returns yet the volatility is the highest comparing to other countries selected for the study justifying the adage: the higher the risk, the higher the returns. The skewness values are negative in nature with respect to each nation making a case that probability of a negative return is higher comparing to positive return. The probability values of the Jarque-Bera test indicate non-normal distribution of the respective return series and further higher kurtosis values (greater than three) imply clustering nature of the returns.

The financial time series data is required to be stationary as non-stationary series would entail spurious regression results (Gujarati et al., 2013). We have used Augmented Dickey Fuller test to check stationarity of the data. The Augmented Dickey Fuller test is a function of lagged values of the dependent variable. The alternate hypothesis signifies the stationarity of the data. The MSCI data is found to be non-stationary at level but stationary after taking the first difference at the 5 percent significance level. We have also checked the stationarity of the financial stress index. The index is also found to be non-stationary at the level but stationary after taking the first difference at the 5 percent significance level.

After checking the stationarity of the data, we performed Johansen Cointegration test to check the presence of any stochastic trend or a long-run co-movement between the financial stress index and MSCI indices. One of the main conditions for the Johansen Cointegration test is that the data should be integrated of the same order I (1). The test comprises two alternate test statistics: 
Trace test and the Maximum Eigenvalue test. Under the Trace test, the alternative hypothesis of cointegration is that the cointegrating vectors are greater than $0\left(h_{1}: r>0\right)$, whereas the alternative hypothesis tests the number of cointegrating vectors as $r+1$ in the case of the Max Eigenvalue test. Under the Johansen methodology, the lag lengths should be appropriate and to fulfil our requirements, we employed VAR model first and determined the maximum number of lags on the basis of Akaike's Information Criteria (AIC) values. The results of the Johansen test are reported in Exhibit 4. The trace test indicates the presence of one cointegrating vector, but the Max Eigenvalue test indicates no cointegrating vectors.

Exhibit 3

Descriptive Statistics (MSCI Index Returns)

\begin{tabular}{lcccc}
\hline \hline & Return_BRIC & Return_Europe & Return_Frontier & Return_USA \\
\hline Mean & 0.789966 & 0.296069 & 0.461415 & 0.506650 \\
\hline Median & 1.558207 & 1.249729 & 1.292051 & 1.142933 \\
\hline Maximum & 15.71472 & 11.31091 & 16.31162 & 10.28517 \\
\hline Minimum & -30.52406 & -14.58630 & -26.86788 & -18.93110 \\
\hline Std. Dev. & 6.591723 & 4.144947 & 5.619984 & 4.180697 \\
\hline Skewness & -1.006184 & -0.974301 & -0.947880 & -1.140631 \\
\hline Kurtosis & 6.380101 & 4.858294 & 7.360727 & 6.219436 \\
\hline Jarque-Bera & 85.11089 & 39.87670 & 124.3542 & 85.62908 \\
\hline Probability & 0.0000 & 0.0000 & 0.0000 & 0.0000 \\
\hline \hline
\end{tabular}

Source: Computed by the Authors.

Exhibit 4

Johansen Cointegration Results

\begin{tabular}{cccc}
\hline \hline Null Hypothesis & Alternate Hypothesis & & 95\% Critical Value \\
\hline Trace test & & Trace value & \\
\hline $\mathrm{r}=0$ & $\mathrm{r}>0$ & 75.73 & 69.82 \\
\hline $\mathrm{r}<=1$ & $\mathrm{r}>1$ & 44.43 & $47.86^{*}$ \\
\hline Max test & & Max value & 33.87 \\
\hline $\mathrm{r}=0$ & $\mathrm{r}=1$ & 31.29 & \\
\hline \hline
\end{tabular}

* Trace test indicates 1 cointegrating equation at the 5 percent significance level.

Source: Computed by the Authors.

As both results are conflicting, we will go by the results reported by the Max Eigenvalue test as the results of the Trace test are indicative in nature (Pentecost \& Moore, 2006). On the other hand, it may be noted that the Johansen approach supports the results reported by the Trace test. So, there is no long-run co-movement or a stochastic trend among the financial stress index and the other MSCI indices taken at logged level. Though there is no long-run co-movement yet there can be short-run relationships among the underlying variables, which we have checked by employing a VAR model. To understand the results of the VAR model, three branches of the model, Granger causality test, impulse responses and variance decomposition analysis are reported. 


\subsection{Stock Market Returns and Financial Stress Index}

The Granger causality test states that if the lagged values of variable $Y_{2}$ help in predicting the values of the dependent variable $Y_{1}$ then $Y_{2}$ Granger-causes $Y_{1}$. Exhibit 5 reports the results of the Granger causality test. The Akaike Information Criteria (AIC) values support the usage of one-month lagged values. One-month lagged returns in the BRIC equity markets $(-0.2439$, p-value $<0.05)$ Granger-cause the financial stress index of India. The p-values are not found to be significant in the case of other countries examined. As a result of growing integration among the BRIC nations (Bhar \& Nikolova, 2008; Dasgupta, 2014), the returns in the BRIC nations have an impact on the Indian financial stress. The coefficient is found to be negative in nature, which makes the case that if the returns in the BRIC countries are positive or in other words a buying spree is present in the BRIC equity markets, then the financial stress in India gets reduced. In the same way, when the returns are negative in the BRIC equity markets as a whole, then that downtrend does add to the financial stress of India. One-month lagged value of the financial stress index has a significant negative $(-0.1718$, $p$-value $<0.05)$ impact on the current financial stress in the Indian economy. On an overall basis, all the markets Granger-cause the financial stress index.

\section{Exhibit 5}

Granger Causality Test Results

\begin{tabular}{lccc}
\hline \hline \multicolumn{1}{c}{ Excluded } & \multicolumn{2}{c}{ Dependent variable: D (FSI) } & \\
\hline Return_BRIC & Chi-square & Degree Of Freedom & Probability \\
\hline Return_EUROPE & 7.455534 & 1 & $0.0063^{*}$ \\
\hline Return_FRONTIER & 0.039158 & 1 & 0.8431 \\
\hline Return_USA & 0.318088 & 1 & 0.5728 \\
\hline All & 0.747094 & 1 & 0.3874 \\
\hline \hline
\end{tabular}

${ }^{*}$ Reject the null hypothesis of no significant relationship at the 5 percent significance level.

Source: Computed by the Authors.

The impulse responses highlight response of respective variables when a shock is subjected to an error term of an endogenous variable. As each variable enters into VAR equation in its lagged form, so it does have an impact on the other variable as well. Exhibit 6 reports the results of generalised impulse responses of the financial stress index as well as the other variables. We are concerned only with the results of the financial stress index which are in the first row. Initially, the response is positive when a shock is given to the US, Europe, frontier and BRIC stock markets. A positive response means that initially the return(s) shocks in these respective markets enhance the financial stress in India. The response becomes negative only after two months in each case and completely dies out after three to four months. In a nutshell, the shock in the equity index returns of the US, Europe, frontier and BRIC markets initially increases the Indian financial stress and the effect dies out after a few months. The investors in the Indian financial markets should consider the impact of a return(s) shock on the Indian financial stress.

After impulse response functions, another branch of the VAR model is the variance decomposition analysis. The analyses highlight contribution of one variable when a shock is subjected to the error terms of the latter in explaining variations in another variable at the time of forecasting. The time-varying contribution of the shocks shows spillover impact of the returns on the financial stress in the Indian economy. Under variance decomposition analysis, the ordering of the variables is very important as per the Cholesky Decomposition framework. We have done the ordering by assuming and placing the US market at the first place, considering its development 

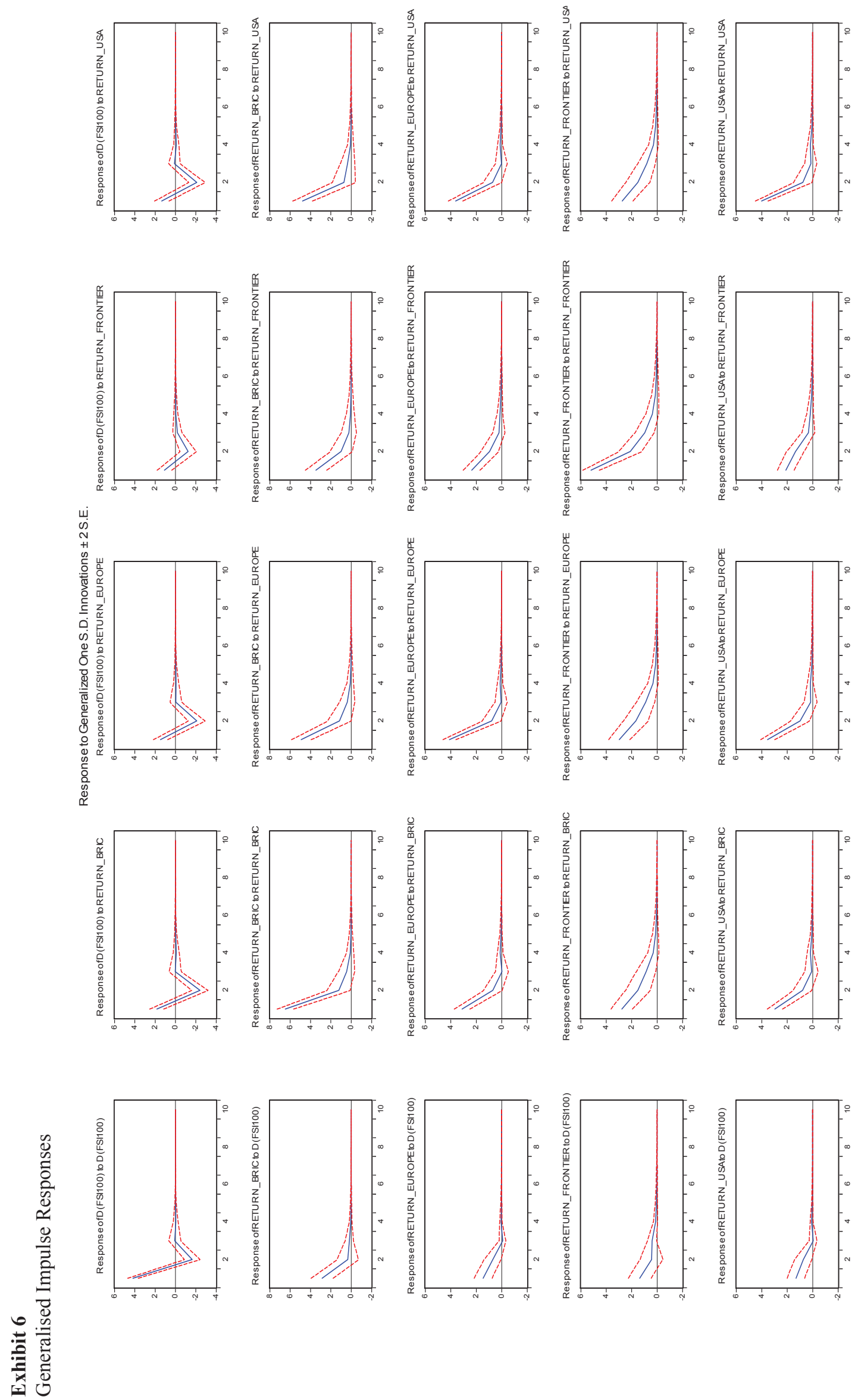

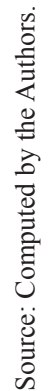


level and European and the BRIC markets at the second and third place respectively. The frontier markets and the financial stress index take the fourth and fifth place respectively. We have drawn out the results for twelve months.

Exhibit 7 reports the results of variance decomposition analysis. In the first month, when a shock is given to the financial stress index, then that contributes around 80 percent of the variation in the financial stress index itself. The US market contributes around 11 percent, whereas the contribution of the BRIC market is low. The contribution of the frontier markets remains negligible throughout the twelve months. During the fifth month, the US market accounts for around 26 percent of the variations, whereas the contribution of the financial stress reduces to approximately 60 percent. The contribution remains more or less similar with respect to all of the endogenous variables after five months.

The results reported by the Vector Autoregression model have further prompted us to study the relationship among the Brazilian, Russian, Chinese equity market returns and Indian financial stress index (excluding Indian market) under the VAR framework. To analyse the impact of the countries, the study uses monthly returns series of the benchmark indices of the respective countries, i.e. BOVESPA (Brazil), Russian Trading System RTS (Russia) and Shanghai Composite index SSE (China). The monthly returns are calculated in the similar fashion as mentioned in eq (1). The Augmented Dickey Fuller test reports stationarity in the data. The Akaike Information Criteria (AIC) values support the usage of two months' lagged values in the model.

\section{Exhibit 7}

Variance Decomposition of D (FSI)

\begin{tabular}{ccccccc}
\hline \hline Period & S.E. & D (FSI) & R_BRIC & R_Europe & R_Frontier & R_USA \\
\hline 1 & 4.173322 & 80.19323 & 7.171757 & 2.019459 & 0.050563 & 10.56499 \\
\hline 2 & 4.884772 & 60.26348 & 10.86562 & 2.437928 & 0.172829 & 26.26014 \\
\hline 3 & 4.899858 & 59.92068 & 10.80023 & 2.753622 & 0.386530 & 26.13894 \\
\hline 4 & 4.900903 & 59.89559 & 10.80164 & 2.754271 & 0.386736 & 26.16177 \\
\hline 5 & 4.901038 & 59.89233 & 10.80151 & 2.756472 & 0.387825 & 26.16187 \\
\hline 6 & 4.901043 & 59.89221 & 10.80150 & 2.756482 & 0.387875 & 26.16193 \\
\hline 7 & 4.901044 & 59.89218 & 10.80150 & 2.756489 & 0.387884 & 26.16195 \\
\hline 8 & 4.901045 & 59.89217 & 10.80150 & 2.756490 & 0.387885 & 26.16195 \\
\hline 9 & 4.901045 & 59.89217 & 10.80150 & 2.756490 & 0.387886 & 26.16195 \\
\hline 10 & 4.901045 & 59.89217 & 10.80150 & 2.756490 & 0.387886 & 26.16195 \\
\hline 11 & 4.901045 & 59.89217 & 10.80150 & 2.756490 & 0.387886 & 26.16195 \\
\hline 12 & 4.901045 & 59.89217 & 10.80150 & 2.756490 & 0.387886 & 26.16195 \\
\hline \hline
\end{tabular}

Source: Computed by the Authors.

One-month and two-month lagged values of the financial stress index have a negative and statistically significant impact on the current financial stress at the 5 percent significance level. The impact of one-month lagged returns in the Brazilian market is positive $(0.2059, \mathrm{p}<0.05)$ and statistically significant. A positive sentiment in the Brazilian market increases the financial stress in the Indian financial market and vice versa for the negative returns. On the other hand, the impact of two months' lagged returns in the Brazilian market becomes negative $(-0.2097$, $\mathrm{p}<0.05$ ) and significant with a similar magnitude. It exhibits that after two months the interaction between the countries concerned becomes more integrated, wherein the positive returns in the Brazilian market also reduce the stress in the Indian financial system and vice versa. Similarly, the 
impact of two months' lagged returns is negative and statistically significant $(-0.0781, p<0.10)$ at the 10 percent significance level in the context of Chinese market returns. The Granger causality results report the impact of only the Brazilian market on the financial stress index at the 5 percent significance level owing to increasing Brazil-India trade relations.

The generalised impulse responses came out with a finding that the response of the Indian financial stress towards the return(s) shocks in the Brazilian, Russian and Chinese markets becomes negative only after two months. As per the variance decomposition analysis, when a shock is given to the Brazilian market then that contributes around 12 percent variation in the financial stress in the second month but the contribution increases to 27 percent in the third month. The contribution of the Russian and Chinese markets remains 1 percent and 2 percent, respectively throughout the 12 months ahead variances. The ordering of the variables has been done considering the VAR model results. Overall, the VAR model is found to be stationary as all of the inverse roots lie inside the unit circle.

Furthermore, we have tried to capture the contemporaneous and dynamic impact of the Brazilian, Russian and Chinese equity market returns (excluding India) on the sub-components of the financial stress index by employing multivariate OLS regression model, wherein we have taken different sub-components as dependent variables and equity market returns in the respective markets as the independent variables. Before employing the model, the stationarity of the subcomponents has been assured first. Exhibit 8 reports the contemporaneous impact of the markets on the sub-components.

\section{Exhibit 8}

Contemporaneous Impact on Sub-Components of the Financial Stress Index

\begin{tabular}{lccccc}
\hline \hline & Bank Spread & $\begin{array}{c}\text { Exchange } \\
\text { Volatility }\end{array}$ & Debt Market & $\begin{array}{c}\text { NIFTY } \\
\text { Returns }\end{array}$ & $\begin{array}{c}\text { NIFTY } \\
\text { Volatility }\end{array}$ \\
\hline Brazil & 0.1631 & $-0.2320^{* *}$ & $0.2846^{*}$ & -0.2364 & 0.2360 \\
\hline Russia & $-0.4619^{*}$ & 0.0683 & -0.0775 & $0.3343^{*}$ & -0.1142 \\
\hline China & $0.4750^{*}$ & 0.0476 & -0.0627 & 0.0807 & -0.0805 \\
\hline \hline
\end{tabular}

Reject null hypothesis of no significant relationship at $5 *$ and $10^{* *}$ percent significance level.

Source: Computed by the Authors.

There is a negative and statistically significant impact of the Russian market returns on the spread between the MIBOR and Treasury bills at the 5 percent significance level depicting increased integration among the markets. The falling returns in the Russian market increase the banking stress in the Indian economy. However, the impact of the Chinese market returns is positive on the banking spread signifying an increased level of banking stress with the positive returns in the Chinese markets. The Brazilian market has a negative $(-0.2320, p<0.10)$ impact on the exchange rate volatility, wherein the falling returns increase the volatility in the Indian exchange rate. However, the Brazilian market has a positive impact on the spread between the 10-year Indian government securities and 10-year US government securities, thereby adding to the financial stress. The returns in the Russian market have a positive and statistically significant impact on the Indian market returns at the 5 percent significance level. There is no evidence of impact of the Brazilian, Russian and Chinese markets on the Indian equity market volatility. Exhibit 9 reports the dynamic impact of one-month lagged returns in the Brazilian, Russian and Indian markets on the sub-components. 
Exhibit 9

Dynamic Impact on Sub-Components of the Financial Stress Index

\begin{tabular}{llllll}
\hline \hline & Bank Spread & $\begin{array}{c}\text { Exchange } \\
\text { Volatility }\end{array}$ & $\begin{array}{c}\text { Debt } \\
\text { Market }\end{array}$ & $\begin{array}{c}\text { NIFTY } \\
\text { Returns }\end{array}$ & $\begin{array}{c}\text { NIFTY } \\
\text { Volatility }\end{array}$ \\
\hline Brazil & -0.0423 & 0.0428 & -0.1109 & $1.0048^{*}$ & 0.0554 \\
\hline Russia & $-0.4689^{*}$ & 0.0525 & 0.0680 & $0.2659^{*}$ & $-0.1670^{* *}$ \\
\hline China & 0.3710 & -0.0097 & 0.0155 & 0.1340 & 0.0978 \\
\hline \hline
\end{tabular}

Reject null hypothesis of no significant relationship at $5 *$ and $10^{* *}$ percent significance level

Source: Computed by the Authors

The one-month lagged returns in the Russian market have a statistically significant impact on the bank spread, NIFTY returns and NIFTY volatility. The impact is negative with respect to the bank spread and NIFTY volatility. A negative return in the Russian market has a positive impact on the financial stress as it would entail an increase in the banking stress and equity volatility. Besides this, there is a strong positive impact of the one-month lagged return in the Brazilian market on the NIFTY returns $(1.0048, \mathrm{p}<0.05)$ at even 1 percent significance level. All of this empirical evidence testifies the importance of liberalising international financial flows, whereby global information transmissions are having an impact on different sub-components of the financial stress index in the form of stress in the money market as well as debt market.

\subsection{Impact of US, Europe and Frontier Equity Market Returns on the Sub-Components}

We further extended our analysis to study the impact of the US, Europe and frontier markets (excluding BRIC markets) on the sub-components of the financial stress index through multivariate OLS regression model. The returns in the frontier markets have a negative impact on the banking spread at the 5 percent significance level both contemporaneously and dynamically. A positive return in the frontier markets reduces the spread in the Indian banking sector, thereby exhibiting an increased level of integration among the markets. Besides this, a positive return in the European markets reduces spread in the Indian debt market segment $(-0.8627, \mathrm{p}<0.05)$ and increases the NIFTY returns $(1.6499, \mathrm{p}<0.05)$ contemporaneously and with a larger magnitude. There is a dynamic negative impact of one-month lagged returns in the European markets on the NIFTY volatility $(-0.7584, \mathrm{p}<0.05)$. A falling return increases volatility in the Indian equity market. Similarly a positive return in the US $(0.4998, \mathrm{p}<0.10)$ and frontier markets $(0.2083$, $\mathrm{p}<0.10$ ) increases the spread in the debt market contemporaneously as the coefficients are found to be significant at the 10 percent level. This means that positive flows to the US and frontier markets increase long-term sovereign debt market risks in the Indian economy.

\subsection{Conditional Volatility and Financial Stress Index}

Lastly, we have studied the impact of the stock market volatility on the financial stress. Exhibit 10 presents the graphical images of the permanent, transitory and the overall conditional variances. In the case of the European markets, the transitory component of the volatility is very volatile in comparison to the other countries examined. A spike can easily be witnessed during the fourth quarter of year 2008 with respect to all of the markets, highlighting the existence of the US subprime loan crisis during that period. We have used the conditional variances derived from the CGARCH $(1,1)$ model to account for the impact of the market volatility in the respective nations on the Indian financial stress and its sub-components. As mentioned earlier, one and two months' lagged values are included in the frontier markets' mean equation model. Both of the lagged values are observed to be having a significant impact on the current frontier markets' returns to 
the tune of around 0.20 percent. This further supports inefficiency in the latter markets owing to significant impact of past month values on the current ones. It is pertinent to mention that all the GARCH based models are found to be adequate in the context of non-existence of serial autocorrelation and heteroskedasticity in the standardised error terms.

\section{Exhibit 10}

Graphical Presentation of the Conditional Variances
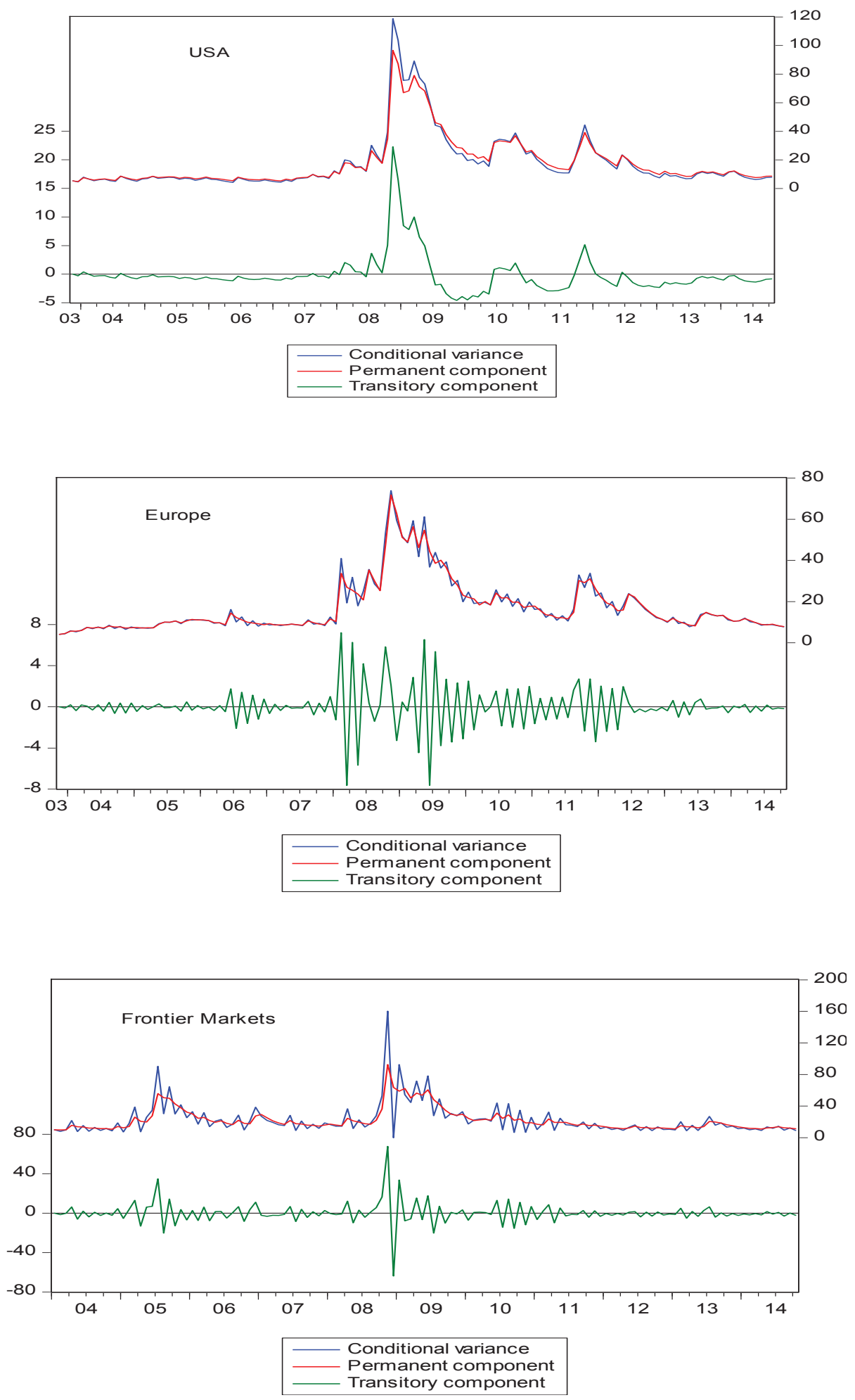


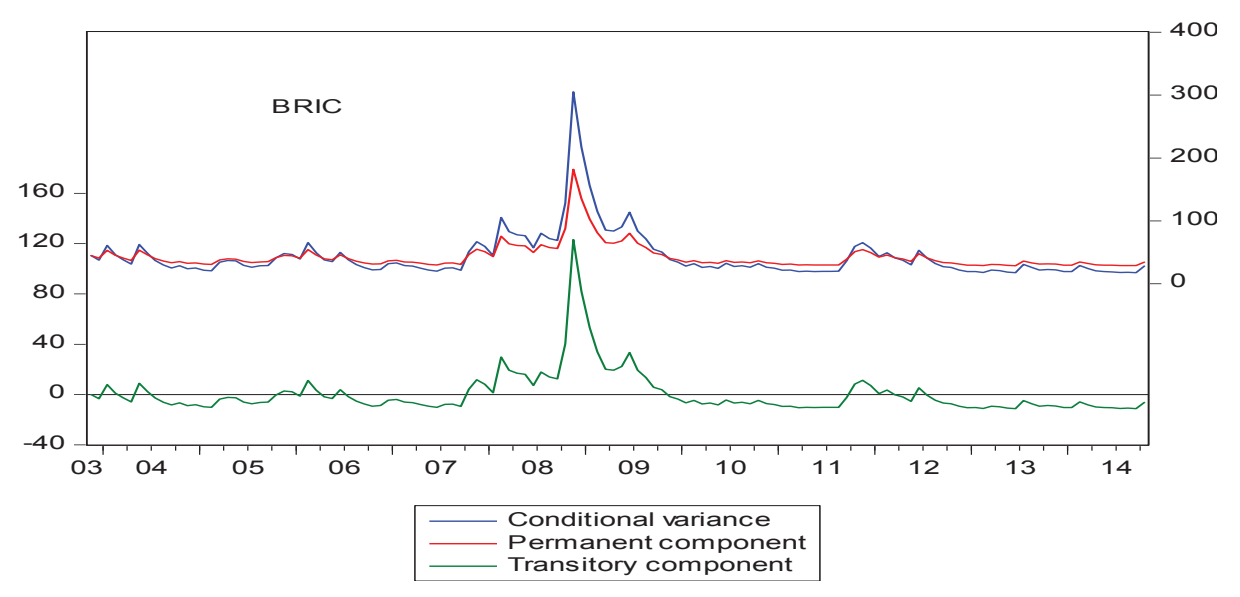

Source: Computed by the Authors.

Exhibit 11 reports the results of impact of the transitory component of volatility on the financial stress index of India. The results are derived by employing multivariate OLS regression model. A statistically significant contemporaneous impact of the short-run volatility running from the European stock market to the Indian financial system has been observed. The coefficient is positive in nature signifying a positive impact on the financial stress whenever there is an increase in the short-run component of the volatility. For the rest of the nations, the impact is not found to be statistically significant at the 5 percent level.

Similarly, when we tried to capture the impact of the long-run component of the conditional variance on the financial stress, then the results are not found to be significant at the 5 percent level. The results of the long-run component of the volatility on the financial stress have not been reported but can be provided on request. Even the impact of one-month lagged volatility (dynamic volatility) on the financial stress is not found to be statistically significant at the 5 percent level in the context of both the short-run as well as long-run component of the conditional volatility.

\section{Exhibit 11}

Transitory Component of Volatility and Financial Stress Index

\begin{tabular}{cccc}
\hline \hline & Coefficient & T-statistic & P-value \\
\hline$\varnothing_{2}$ & -0.0019 & -0.0416 & 0.9668 \\
\hline$\varnothing_{3}$ & 0.2429 & 1.0123 & 0.3133 \\
\hline$\varnothing_{4}$ & 0.6024 & 3.1213 & $0.0022^{*}$ \\
\hline$\varnothing_{5}$ & -0.0055 & -0.1498 & 0.8811 \\
\hline \hline
\end{tabular}

*Reject null hypothesis of no significant relationship at the 5 percent significance level.

Source: Computed by the Authors.

Exhibit 12 reports the results of impact of unexpected volatility in the markets of the US, Europe, BRIC and frontier markets on the Indian financial stress. The unexpected volatility in the BRIC stock markets has a positive and statistically significant impact on the Indian financial stress contemporaneously with a larger magnitude. The dynamic impact (one-month lagged) of the unexpected volatility in the BRIC stock markets statistically reduces the financial stress in the Indian economy. 
Exhibit 12

Impact of Unexpected Component of Volatility on Financial Stress Index

\begin{tabular}{ccccccc}
\hline \hline & \multicolumn{2}{c}{ Contemporaneous Impact } & \multicolumn{3}{c}{ Dynamic Impact } \\
\hline & Coefficient & T-stat & P-value & Coefficient & T-stat & P-value \\
\hline$\infty_{2}$ & 1.2370 & 2.0818 & $0.0394^{*}$ & -1.1450 & -2.0877 & $0.0389^{*}$ \\
\hline$\infty_{3}$ & -0.3982 & -0.5077 & 0.6125 & -0.7249 & -0.9903 & 0.3239 \\
\hline$\infty_{4}$ & 0.6695 & 0.8107 & 0.4190 & -0.3814 & -0.4951 & 0.6214 \\
\hline$\infty_{5}$ & -0.2414 & -0.4981 & 0.6193 & -0.3764 & -0.8370 & 0.4042 \\
\hline \hline
\end{tabular}

* Reject null hypothesis of no significant relationship at the 5 percent significance level.

Source: Computed by the Authors.

In other words, the same month unexpected volatility in the BRIC markets adds to the financial stress, whereas the one-month lagged unexpected volatility in the BRIC markets reduces the financial stress exhibiting a reducing impact of the past unexpected variations. The values are not found to be significant for the other countries. Similar types of results were reported by the regression model when we took transitory component and unexpected volatility component simultaneously in the regression equation in terms of both the contemporaneous as well as dynamic impact at 5 and 10 percent level. The unexpected variations in the market make the investors expect a risk premium for holding riskier emerging market assets (Kumar \& Dhankar, 2009). The expectations of high risk premiums in the BRIC equity markets further reduce the stock market returns coupled with increased volatility adding to the financial stress.

To understand the behaviour of the Indian financial stress in a much more calibrated manner, we have tried to analyse the impact of the individual Brazilian, Russian and Chinese markets' conditional volatility (excluding India) on the Indian financial stress index by employing multivariate OLS regression model, wherein the conditional variances are taken as independent variables and financial stress index as dependent variable. Surprisingly, we could not find any ARCH effects in the Brazilian market. So we have studied the impact of only the Russian and Chinese markets' conditional volatility on the Indian financial stress. The results reported that there is no statistically significant impact of the unexpected volatility in the Russian and Chinese markets on the Indian financial stress index either contemporaneously or dynamically. This means that the impact of the BRIC markets' unexpected volatility is largely due to the impact of the Indian market itself on the financial stress. On a similar note, the stress in the Indian financial system does not get affected by the permanent volatility in the Russian and Chinese markets. However, the short-run volatility in the Chinese market has a reducing impact on the Indian financial stress $(-0.0642, \mathrm{p}<0.05)$ contemporaneously, whereas the impact becomes positive after one month $(0.0462, \mathrm{p}<0.05)$ with a lesser magnitude. Furthermore, the impact of the unexpected volatility in the Russian and Chinese markets on the sub-components of the financial stress index is not found to be statistically significant at the 5 percent significance level, either contemporaneously or dynamically barring the positive and stronger dynamic impact of one-month lagged unexpected volatility in the Russian (5.5164, $\mathrm{p}<0.05)$ and Chinese market $(2.3239, \mathrm{p}<0.05)$ on the NIFTY returns. The permanent volatility in the Russian market has a significant positive and negative impact on the banking spread and exchange rate volatility respectively in a longer period (dynamic impact). Even the transitory component has a positive impact on the banking spread. The debt market spread and NIFTY volatility also gets positively influenced by the transitory volatility in the Chinese market $(0.0729, p<0.05)$ and the Russian market $(0.0676, \mathrm{p}<0.05)$ respectively, after one month. There is a contemporaneous negative impact of transitory volatility in the Chinese market $(-0.1391, \mathrm{p}<0.05)$ and the Russian market $(-0.0446, \mathrm{p}<0.05)$ on the NIFTY returns. If the short-run volatility in the Chinese market increases by 1 percent then the returns in the Indian market reduces by 0.1391 percent. 


\subsection{Impact of US, Europe and Frontier Markets Volatility on the Sub-Components}

We extended our analysis to study the impact of the US, European and frontier markets' volatility (excluding BRIC markets) on the sub-components of the financial stress index by employing multivariate OLS regression model. The permanent component of the volatility in the European market increases banking spread in the Indian economy both contemporaneously and dynamically. However, permanent volatility in the US market dynamically reduces NIFTY volatility $(-0.3389, \mathrm{p}<0.05)$ and has an increasing impact on the NIFTY returns $(0.4127, \mathrm{p}<0.05$ and $0.4507, \mathrm{p}<0.05)$ both contemporaneously and dynamically. The permanent volatility in the European markets has a reducing impact on the NIFTY returns $(-0.6184, \mathrm{p}<0.05$ and -0.6826 , $\mathrm{p}<0.05)$ both contemporaneously and dynamically with a stronger magnitude. Similarly, onemonth lagged permanent volatility in the European market has a reducing dynamic impact on the exchange rate volatility in the Indian economy $(-0.2571, \mathrm{p}<0.10)$, whereas it dynamically increases the volatility in the Indian equity market $(0.4515, \mathrm{p}<0.05)$.

The transitory component of the volatility in the US market increases banking spread in the Indian market, thereby adding to the banking stress in the short run $(2.8587, \mathrm{p}<0.01$ and 2.6183 , $\mathrm{p}<0.01$ ) both contemporaneously and dynamically, whereas, on the other hand, the transitory volatility in the US $(-0.3106, p<0.10)$ and frontier markets $(-0.1002, p<0.05)$ contemporaneously reduces exchange rate volatility in the Indian market to the tune of around 0.31 and 0.10 percent respectively. On a similar note, transitory volatility in the US $(0.6814, \mathrm{p}<0.01)$ and frontier markets $(0.2774, p<0.01)$ contemporaneously increases volatility in the Indian equity market, and the impact of the US market is observed to be higher. One-month lagged transitory volatility in the European markets has a reducing dynamic impact on the exchange rate volatility $(-0.5163, p<0.05)$ at the 5 percent significance level, whereas the impact is strongly positive on the Indian equity market volatility $(1.0148, \mathrm{p}<0.01)$ dynamically. Similarly, one-month lagged transitory volatility in the frontier markets has a reducing dynamic impact on the debt spread $(-0.0894, p<0.10)$.

The unexpected component of the volatility in the European market has a strong reducing impact on the debt spread in the Indian market $(-2.4148, \mathrm{p}<0.05)$ contemporaneously. There is a contemporaneous negative impact of the unexpected volatility in the European market on Indian exchange rate volatility at the 10 percent significance level $(-1.8518, p<0.10)$. The Indian equity market returns are greatly influenced by the unexpected volatility in the US, European and frontier markets, as all the coefficients are found to be significant at 5 and 10 percent significance level contemporaneously. Moreover, one-month lagged unexpected volatility in the frontier markets has a dynamic reducing impact on the banking spread at the 10 percent significance level. Interestingly, unexpected volatility in the respective markets does not have a statistically significant impact on the Indian equity market volatility either dynamically or contemporaneously.

\section{CONCLUDING REMARKS}

Studies relating to information transmission across different countries are of paramount interest to the international investors. The cross-market impact highlights sensitivity of the domestic economies to the foreign information elements. However, the present study adds to the literature by capturing the impact of the said global information transmissions on Indian financial stress index and its various sub-components. To study the impact of the US, Europe, frontier and BRIC stock markets on the Indian financial stress index, we have primarily employed Vector Autoregression and Component GARCH $(1,1)$ models with the monthly data ranging from year 2003 to 2014. In order to construct the financial stress index, four major segments of the financial system: Equity market, Debt market, Foreign Exchange market and the Money market are taken into consideration. The Johansen Cointegration test indicates that there is no long-run 
co-movement between the financial stress index and the MSCI indices of the respective nations. So, there are short-run dynamic interactions among the respective equity markets and financial stress index that channelize the impact of equity markets on the latter. Overall, the results of the VAR model report that only the BRIC market returns contribute to the financial stress index. The short-term dynamic relationship is negative in nature, wherein positive returns in the BRIC nations reduce stress in the Indian financial system highlighting increasing integration among the markets. The impulse responses of the financial stress index dies out after three to four months, whereas the contribution of the US market to the variations in the financial stress index increases over a period of time. The stress in the Indian financial system responds statistically significantly to the Brazilian and Chinese market returns. The banking spread, NIFTY returns and NIFTY volatility component of the stress index gets strongly influenced by the one-month lagged Russian market returns but there is no significant impact of the Russian market returns on the overall financial stress. Moreover, a positive return in the European market reduces the spread in the Indian debt market segment and increases the NIFTY returns contemporaneously and with a larger magnitude.

A statistically significant impact of the short-run component of the volatility in the European market on the Indian financial stress has also been found. Further, the unexpected volatility in the BRIC markets has a significant impact on the Indian financial stress. But the impact of the BRIC markets' unexpected volatility is largely due to the impact of the Indian market itself on the financial stress. There is a positive and a stronger dynamic impact of one-month lagged unexpected volatility in the Russian and Chinese markets on the NIFTY returns. Both the permanent and transitory components of the volatility in the European market have a strong and significant positive impact on the NIFTY volatility dynamically. On the other hand, the permanent component of the conditional volatility in the US market helps in reducing overall financial stress because it increases the NIFTY returns both contemporaneously and dynamically and also reduces the NIFTY volatility with a lagged impact. The results show that, notwithstanding, most of the countries do not have a statistically significant impact on the overall financial stress but they do have an impact on the sub-components in a much more calibrated manner owing to response of respective sub-components towards global information transmissions. The impact of the stock markets on the sub-components of the financial stress also spotlights the transmission channels through which these equity market spillovers have an impact on the financial stress.

A stock market discounts every type of information in advance and positive behaviour in the market indicates wellness of the economy as a whole. The investments in the BRIC stock markets by the international investors exhibit overall positive behaviour of the investors toward the emerging nations, which further entails increased inflows of foreign funds in the latter markets. This positive behaviour also helps in reducing stress in the overall financial system because these foreign financial flows have a spillover impact on the other sub-components of the financial system as well, like favourable banking spreads, reduced debt market spreads and lower exchange rate volatility. A general conclusion that can be drawn from the study is that the BRIC markets in the first as well as second moment and the European markets in the second moment have a direct and statistically significant impact on the Indian financial stress index in the short run. A possible reason that could be attributed to the Indian financial stress being sensitive to the European shortrun volatility in the markets can be monetary stimulus policies adopted by the European nations, hence increasing financial flows. The policy makers and especially the investors in the financial markets comprising equity, debt and currency should discount the information coming from the European stock markets and the BRIC stock markets because these markets have an impact not only on the overall financial stress in the Indian economy but also on the core sub-components of the financial system with a greater magnitude as compared to others. Moreover, different monetary policy initiatives are also undertaken considering the co-movement and dynamic interactions among the underlying markets due to the international transmission of shocks through equity 
markets and confidence levels (Berben \& Jansen, 2005). As a future scope of research, the other components or participants of the global financial markets may have an impact on overall Indian financial stress and its sub-components.

\section{Acknowledgements}

We are grateful to the anonymous referees for providing many insightful suggestions. We would also like to express our gratitude to Dr. Navneet Kaur for assisting in data collection.

\section{References}

Angkinand, A.P., Barth, J.R., Kim, H. (2010), Spillover effects from the U.S. financial crisis: Some time-series evidence from national stock returns. In G. Benton (Ed.), The Financial and Economic Crises: An International Perspective (pp. 24-52). Cheltenham, UK: Edward Elgar.

Balakrishnan, R., Danninger, S., Elekdag, S., Tytell, I. (2011), The Transmission of Financial Stress from Advanced to Emerging Economies. Emerging Markets Finance and Trade, 47(2), pp. 40-68.

Berben, R., Jansen, W.J. (2005), Comovement in international equity markets: A sectoral view. Journal of International Money and Finance, 24(5), pp. 832-857.

Bhar, R., Nikolova, B. (2007), Analysis of Mean and Volatility Spillovers using BRIC Countries, Regional and World Equity Index Returns. Journal of Economic Integration, 22(2), pp. 369-381.

Bianconi, M., Yoshino, J.A., Machado, M.O. (2013), BRIC and the U.S. financial crisis: An empirical investigation of stock and bond markets. Emerging Markets Review, 14, pp. 76-109.

Bollerslev, T. (1986), Generalized Autoregressive Conditional Heteroskedasticity. Journal of Econometrics, 31, pp. 307-327.

Booth, G.G., So, W.R., Tse, Y. (1999), Price discovery in the German equity index derivatives markets. The Journal of Futures Markets, 9(6), pp. 619-643.

Christie, A.A. (1982), The stochastic behavior of common stock variances: Value, leverage and interest rate effects. Journal of Financial Economics, 10, pp. 407-432.

Christopoulos, A.G., Mylonakis, J., Koromilas, C. (2011), Measuring the Impact of Financial crisis on International Markets: An Application of the Financial Stress Index. Review of European Studies, 3(1), pp. 22-34.

Dasgupta, R. (2014), Integration and dynamic linkages of the Indian stock market with BRIC: An empirical study. Asian Economic and Financial Review, 4(6), pp. 715-731.

Davig, T., Hakkio, C. (2010), What Is the Effect of Financial Stress on Economic Activity? Retrieved from https:// www.kansascityfed.org/publicat/econrev/pdf/10q2Davig_Hakkio.pdf

Ding, Z., Granger, C.W.J., Engle, R.F. (1993), A long memory property of stock market returns and a new model. Journal of Empirical Finance, 1(1), pp. 83-106. doi: 10.1016/0927-5398(93)90006-D.

Dooley, M.P., Hutchison, M.M. (2009), Transmission of the U.S. subprime crisis to emerging markets: Evidence on the decoupling-recoupling hypothesis. Retrieved from http://sciie.ucsc.edu/workingpaper/2009/ DooleyHutchison\%20\%20Emerging\%20Mrkt\%20linkages\%20March\%2031.pdf

Enders, W. (2014), Applied Econometric Time Series. New Jersey: John Wiley \& Sons.

Frank, N., Hesse, H. (2009), Financial Spillovers to Emerging Markets During the Global Financial Crisis. Retrieved from http://core.ac.uk/download/pdf/6605059.pdf

Gagnon, L., Karolyi, A.G. (2006), Price and volatility transmission across borders. Financial Markets, Institutions and Instruments, 17(3), pp. 107-158.

Goldstein, M., Xie, D. (2009), The Impact of the Financial Crisis on Emerging Asia. Retrieved from http://www. frbsf.org/economic-research/files/09_Goldstein.pdf

Gujarati, D., Porter, D., Gunasekar, S. (2013), Basic Econometrics. New Delhi: McGraw Hill Education.

Hakkio, C.S., Keeton, W.R. (2009), Financial stress: What is it, How can it be measured, and Why does it matter? Economic Review, $Q(\mathrm{II})$, pp. 5-50.

Illing, M., Liu, Y. (2006), Measuring financial stress in a developed country: An application to Canada. Journal of Financial Stability, 2(3), pp. 243-265.

Kharchenko, I., Tzvetkov, P. (2013), Estimation of Volatilities and Spillover Effects Between Developed and Emerging Market Economies. Retrieved from http://lup.lub.lu.se/luur/download?func=downloadFile\&recordOId=3801343 \&fileOId $=3813321$

Kliesen, K.L., Owyang, M.T., Vermann, E.K. (2012), Disentangling Diverse Measures: A Survey of Financial Stress Indexes. Federal Reserve Bank of St. Louis Review, 94(5), pp. 369-397. 
Kumar, R., Dhankar, R.S. (2009), Asymmetric Volatility and Cross Correlations in Stock Returns under Risk and Uncertainty. Vikalpa: The Journal for Decision Makers, 34(4), pp. 25-36.

Lall, S., Cardarelli, R., Elekdag, S. (2008), Financial Stress and Economic Downturns. Retrieved from http://www. imf.org/external/pubs/ft/weo/2008/02/pdf/c4.pdf

Manamperi, N.P. (2015), A Comparative Analysis on US Financial Stress Indicators. International journal of Economics and Financial issues, 5(2), pp. 613-623.

Morales, M.A., Estrada, D. (2010), A financial stability index for Colombia. Annals of Finance, 6, pp. 555-581.

Mukherjee, K.N., Mishra, R. (2010), Stock Market Integration and Volatility Spillover: India and its Major Asian Counterparts. Research in International Business and Finance, 24(2), pp. 235-251.

Park, C., Mercado, R.V. (2013), Determinants of financial stress in Emerging Market Economies. Retrieved from http://www10.iadb.org/intal/intalcdi/PE/2013/12502.pdf

Pentecost, E.J., Moore, T. (2006), Financial Liberalisation in India and a New Test of the Complementarity Hypothesis. Economic Development and Cultural change, 54(2), pp. 487-502.

Rachdi, H. (2013) The Impact of the International Financial Crisis on the Stock Market Return: The Case of Tunisian Stock Exchange. Journal of Empirical Economics, 1(2), pp. 67-74.

Rittler, D. (2012) Price discovery and volatility spillovers in the European Union emissions trading scheme: A highfrequency analysis. Journal of Banking \& Finance, 36(3), pp. 774-785.

Roye, B.V. (2014) Financial Stress and economic activity in Germany and the Euro Area. Empirica, 41(1), pp. 101-126. doi: $10.1007 / \mathrm{s} 10663-013-9224-0$

Sandahl, F., J., Holmfeldt, M., Rydén, A., Strömqvist, M. (2011), An index of financial stress for Sweden. Sveriges riksbank economic review, 2, pp. 49-67.

Sims, C.A. (1980), Macroeconomics and Reality. Econometrica, 48(1), pp. 1-48.

Sum, V. (2013), Impulse Response Functions and Causality Test of Financial Stress and Stock Market Risk Premiums. International Journal of Financial Research, 4(1), pp. 1-4.

Wallace, C. (2013), Financial Stress and its Impact on Economic Activity: Evidence from Jamaica. Retrieved from http://www.ccmf-uwi.org/files/publications/conference/2013/1_2-Wallace-p.pdf

Worthington, A., Higgs, H. (2004), Transmission of equity returns and volatility in Asian developed and emerging markets: A multivariate GARCH analysis. International journal of finance and economics, 9(1), pp. 71-80.

Yiu, M.S., Ho, W.Y.A., Jin, L. (2010), A Measure of Financial Stress in Hong Kong Financial Market — the Financial Stress Index. Retrieved from http://www.hkma.gov.hk/media/eng/publication-and-research/research/researchnotes/RN-02-2010.pdf 